\title{
Measurement of Mammary Blood Flow in Lactating Camels (Camelus dromedarius) Using Antipyrine Absorption Method
}

\author{
Falah K. Al Ani* and Said Al Ghenaimi \\ College of Applied \& Health Sciences, A'Sharqiyah University, P.O. Box 42 Code 400, Ibra, Sultanate of Oman \\ *Corresponding author: dralani8833@gmail.com
}

Article History: 20-101 Received: $15-A p r-20 \quad$ Revised: 27-Aug-20 Accepted: $29-A u g-20$
ABSTRA C T
Mammary blood flow has been measured in human breast as well as cow, sheep and goat udders. According to the
available literature, mammary blood flow has not been measured in lactating camels. So, the objective of this research
was to measure mammary blood flow (MBF) in lactating camel. Data from two lactating camels were used to measure
MBF using the antipyrine absorption method. Following complete manual removal of the milk from the udder, $3 \mathrm{~g}$ of
antipyrine dissolved in 30mL of distilled water was injected into each udder gland by the teat orifice. Blood samples
were collected simultaneously from the left and right milk veins and pulmonary artery at $15,20,25,30,35$, and 40
minutes following the infusion of antipyrine. Oxytocin (20IU) was injected intravenously 45 min following the infusion
of antipyrine, and the volume of the milk removed by manual milking from each udder quarter was measured.
Concentrations of antipyrine in the milk and blood were calculated, and MBF per udder gram per minute was measured.
Results showed MBF of $6250 \mathrm{ml} / \mathrm{min}(9000 \mathrm{~L} / 24 \mathrm{~h})$ for camel number 1 and $7800 \mathrm{ml} / \mathrm{min}(11232 \mathrm{~L} / 24 \mathrm{~h})$ for camel number
2. Blood to milk ratios were $1200: 1$ and $1021: 1$ for camel number 1 and 2, respectively. MBF per gram of udder weight
was $735.29 \mathrm{ml} / \mathrm{min} / \mathrm{g}$ and $829.78 \mathrm{ml} / \mathrm{min} / \mathrm{g}$ for camel number 1 and 2 , respectively.

Key words: Physiology, Mammary gland, Blood flow, Antipyrine absorption method, Lactating camel.

(C2020 IJVS - All Rights Reserved

\section{INTRODUCTION}

The mammary gland is unique among glands in that it is non-functional except during lactation. Several authors have described the anatomy of the mammary gland of camels (Smuts et al. 1987; Al-Ani 2004). They found that camel mammary glands are composed of four glands, each of which ends with one teat. These glands are grouped together in a structure, the udder. The growth rate of mammary gland increases following puberty, greatly accelerates during pregnancy, reaches its greatest development during lactation period and involutes after lactation ceases (Lacasse and Prosser 2003; Delamaire and Guinard-Flament 2006). The caudal epigastric and external pudendal arteries branch from the pudendoepigastric trunk are the main arterial blood supplies of the udder (Smuts et al. 1987). An additional third udder artery includes multiple perineal arteries that supply blood to a small portion of the posterior dorsal part of the udder. It has been reported that milk production and the pudendoepigastric are strongly correlated (Maltz et al. 1984). MBF has been successfully studied in women using Doppler ultrasound (Geddes et al. 2012), in cattle using color Doppler ultrasonography (Kennedy et al. 2019), in goats using the ultrasound
Doppler technique (Christensena et al. 1989), in sheep using methionine arterio-venous differences for the calculation of MBF (Davis and Bickerstaffe 1978), and in sow using ultrasonic transit time flow probe (Renaudeau et al. 2002). No data are available on MBF of camels (Camelus dromedarius). This paper describes the MBF in two lactating camels using antipyrine absorption method.

\section{MATERIALS AND METHODS}

Subjects are two lactating camels, ages seven and nine years, in their third lactation periods. They were kept in a small pasture and fed $10 \mathrm{~kg}$ grain mixture per day with free access to green pasture, alfalfa hay and water. Following parturition, both were milked twice daily. Experimental procedures were conducted according to recommendations of the ethical roles and approved by the ethical committee.

\section{Venous Catheterization}

A $130 \mathrm{~cm}$ polyethylene catheter (Clay Adams, Division of Becton, Parsippany, NJ) PE-100 was introduced into the right jugular vein via a 13-gauge needle and advanced until the proximal end was in the pulmonary

Cite This Article as: Al Ani FK and Ghenaimi SA, 2021. Measurement of mammary blood flow in lactating camels (Camelus dromedarius) using antipyrine absorption method. International Journal of Veterinary Science 10(1): 69-71. https://doi.org/10.47278/journal.ijvs/2020.008 
artery as determined by pressure recording physiography. The left and right cranial superficial epigastric veins (milk veins) were catheterized with a $10 \mathrm{~cm}$ polyethylene catheter (PE-100) introduced through a 13-gauge needle. All catheters were flushed with heparinized saline $(100 \mathrm{IU} / \mathrm{ml})$, secured in position and capped with 3-way stopcock.

\section{Mammary Blood Flow Measurements}

Measurements of blood flows in two lactating camels were made by utilizing the antipyrine absorption method as described by Rasmussen (1965) and modified by Hartmann and Kronfeld (1973) by using the pulmonary artery rather than the jugular vein for measuring antipyrine blood concentration. Estimation of antipyrine concentration in the blood was performed according to the method described by Brodie et al. (1949).

Following complete manual removal of the milk from the udder, $3 \mathrm{gm}$ of antipyrine dissolved in $30 \mathrm{ml}$ of distilled water was injected into each udder gland by the teat orifice and the udder was massaged. Blood samples were collected simultaneously from the left and right milk veins and pulmonary artery at $15,20,25,30,35$, and 40 min following the infusion of antipyrine. Oxytocin (20IU) was injected intravenously 45 minutes following the infusion of antipyrine, and the volume of the milk removed by manual milking from each udder quarter was measured. Concentrations of antipyrine in the milk and blood were calculated (Brodie et al. 1949). MBF per udder gram per minute was measured as described by Rasmussen (Rasmussen, 1963 1965). Both camels were humanely slaughtered and the mammary glands removed and weighted.

\section{RESULTS}

$\mathrm{MBF}$ was $6250 \mathrm{ml} / \mathrm{min}(9000 \mathrm{~L} / 24 \mathrm{~h})$ for camel number 1 and $7800 \mathrm{ml} / \mathrm{min}(11232 \mathrm{~L} / 24 \mathrm{~h})$ for camel number 2 three weeks following calving, that is $104 \sim 130 \mathrm{ml} \mathrm{MBF}$ per sec. Milk production was $7.5 \mathrm{~kg}$ per day for camel number 1 and $11 \mathrm{~kg} /$ day for camel number 2 . The blood to milk ratios were 1200:1 and 1021:1 for the camel number 1 and 2, respectively. Also, the $\mathrm{MBF}$ per gram of the udder was 735.29 and $829.78 \mathrm{ml} / \mathrm{min} / \mathrm{g}$ for camel number 1 and 2 , respectively. In comparison between MBF of camel with that of human breast and cow udder, camels have higher MBF per $100 \mathrm{ml}$ milk production per minute (Table 1).

\section{DISCUSSION}

MBF has been successfully studied in human breast, cow, sheep and goat udders. Camels differ from cattle, sheep and goats in the initiation of milk ejection and milk let down (Thompson and Pike 1973). In camels, milk let down happens only when stimulation of the teat by the calf mouth or by hand massage via initiation of nervous impulses to the hypothalamus, which stimulates the posterior pituitary gland to release oxytocin into bloodstream. At this stage MBF increases drastically to produce milk and milk ejection (Al-Ani 2004). In this case, the blood supply to the mammary gland is extremely important for mammary function. All of the milk precursors come from blood. This study showed that 1021 to 1200 liters of blood passes through the udder for each
Table 1: A comparison between mammary blood flow (MBF) of women breast and camel and cow udders reported by different authors

\begin{tabular}{|c|c|c|c|}
\hline Species & $\begin{array}{l}\text { MBF (ml } \\
\text { blood/ min) }\end{array}$ & $\begin{array}{l}\text { MBF (ml } \\
\text { blood/dl } \\
\text { milk/min) }\end{array}$ & References \\
\hline Women & 72.5 & 29.0 & Geddes et al. (2012) \\
\hline Camel \# 1 & 6250 & 70.9 & Present Study \\
\hline Camel \# 2 & 7800 & 83.3 & Present Study \\
\hline Cow & 9620 & 32.0 & $\begin{array}{l}\text { Al-Ani and Vestweber } \\
\text { (1984) }\end{array}$ \\
\hline
\end{tabular}

one liter of milk synthesized. Also, the result showed that camels with higher MBF produced more milk than those with lower flow. Other studies reported 400 to 500 liters blood circulation produce 1 liter of milk in cattle, 470 liter in sows and $236 \mathrm{~L} / 24 \mathrm{~h}$ in human breast milk (Thompson and Pike 1973; Renaudeau 2002; Geddes et al. 2012). This means a cow producing $30 \mathrm{~L}$ of milk per day circulates $15,000 \mathrm{~L}$ of blood through the mammary gland. Thus, the high producing dairy cow of today is exposed to very extreme demands (Götze et al. 2010). Gorewit et al. (1989) reported an increase of two- to six-fold blood flow in the mammary gland beginning two to three days prepartum. So, measurement of mammary blood flow is important to study the potential capacity of the udder to produce milk. Current results showed MBF per gram of the udder was $735.29 \mathrm{ml} / \mathrm{min} / \mathrm{g}$ and $829.78 \mathrm{ml} / \mathrm{min} / \mathrm{g}$ for camel number 1 and 2, respectively. The MBF in normal breasts of women versus cancerous breasts were $5.6 \pm 1.4 \mathrm{ml} / \mathrm{dl} / \mathrm{min}$ and $29.8 \pm 17 \mathrm{ml} / \mathrm{dl} / \mathrm{min}$, respectively (Wilson et al. 1992). In another study by using color Doppler ultrasound, mammary blood flows in 55 lactating women were $126 \mathrm{~L} / 24 \mathrm{~h}$ for the left breast and $110 \mathrm{~L} / 24 \mathrm{~h}$ for the right breast (Geddes et al. 2012). In cattle using antipyrine absorption method, MBF was $9620 \mathrm{ml} / \mathrm{min}$ in dairy cows producing 30L/day (Al-Ani and Vestweber 1984). In another study by used color Doppler sonography to measure $\mathrm{MBF}$ in lactating cows and found $22.3 \mathrm{~L} / \mathrm{min}$ (Götze et al. 2010). The ultrasound Doppler technique was used in a dry goat yielded a MBF of 90 to $675 \mathrm{ml} / \mathrm{min}$ contrasted with a high-yielding lactating goat of $3.41 \mathrm{~L}$ milk/day (Christensena et al. 1989). The MBF of five ewes, measured by methionine arterio-venous difference, varied between 0.53 and $1.43 \mathrm{~L} / \mathrm{min}$ (Davis and Bickerstaffe, 1978).

Bedouin reported that some camel lactation periods are too short, only three to six months, while other camels may extend lactation up to two years with good milk production (Al-Ani 2004). This highlights the need for further study to discover the relationship between MBF, lactation period and milk production volume. Other lactating animals such as cows, goats and sheep, exhibit conflicting results between relationships between MBF and milk production. Some researchers found positive relationships while others found none (Linzell 1974; Maltz 1984; Lacasse and Prosser 2003).

\section{Conclusion}

This study reported for the first time the MBF in two lactating camels. Results showed MBF of $6250 \mathrm{ml} / \mathrm{min}$ $(9000 \mathrm{~L} / 24 \mathrm{~h})$ for camel number 1 and $7800 \mathrm{ml} / \mathrm{min}$ 
(11232L/24h) for camel number 2, respectively. Lactating camels with higher MBF produced more milk.

\section{Significance}

Presently, there are large demand on camel milk especially after the discovery of its efficacy in prevention the occurrence of human diabetes mellitus and cancer. This study discovered that increase in $\mathrm{MBF}$ increase milk secretion. This study will help the researchers to conduct more research on $\mathrm{MBF}$ that many researchers were not able to explore if there is relationship between MBF and milk production in human breast and cow udder. Thus, more studies must be conducted to find out the relationship between MBF, milk production and amount of concentrate feeding per day. This can be done by studying MBF at dry period of lactation and during the different stages of lactation. Geddes et al. (2012) reported that well established knowledge of mammary blood flow in women is almost all based on animal studies.

\section{REFERENCES}

Al-Ani FK and Vestweber JG, 1984. Mammary blood flow measurements associated with the development of bovine udder edema. American Journal of Veterinary Research 45: 339-341.

Al-Ani FK, 2004. Camel Management and Diseases. $1^{\text {st }}$ Ed. Dar Ammar Book Publisher, Jordan.

Brodie BB, Axelrod J, Soberman R, et al. 1949. The estimation of antipyrine in biological materials. The Journal of Biological Chemistry 179: 25-29.

Christensena K, Nielsena MO, Bauer R and Hilden K, 1989. Evaluation of mammary blood flow measurements in lactating goats using the ultrasound doppler principle. Comparative Biochemistry and Physiology Part A: Physiology 92: 385-392.

Davis SR and Bickerstaffe AR, 1978. Mammary glucose uptake in the lactating ewe and the use of methionine arterio-venous difference for the calculation of mammary blood flow. Australian Journal of Biological Sciences 31: 133-139.

Delamaire E and Guinard-Flament J, 2006. Increasing milking intervals decreases the mammary blood flow and mammary uptake of nutrients in dairy cows. Journal of Dairy Science 89: 3439-3446. https://doi.org/10.3168/jds.S0022-0302(06) 72381-5

Geddes DT, Aljazaf KM, Kent JC, Prime DK, Spatz DL, Garbin CP, Lai CT and Hartmann PE, 2012. Blood flow characteristics of the human lactating breast. Journal of
Human Lactation 28: 145-152. https://doi.org/10.1177/ $\underline{0890334411435414}$

Gorewit RC, Aromando MC and Bristol DG, 1989. Measuring bovine mammary blood flow using a transit time ultrasonic flow probe. Journal of Dairy Science 72: 1918-1928. https://doi.org/10.3168/jds.S0022-0302(89)79311-5

Götze PA, Honnens A, Flachowsky G and Bollwein H, 2010. Variability of mammary blood flow in lactating HolsteinFriesian cows during the first twelve weeks of lactation. Journal of Dairy Science 93: 38-44. https://doi.org/10.3168/ jds.2008-1781

Hartmann PE and Kronfeld DS, 1973. Mammary blood flow and glucose uptake in lactating cows given dexamethasone. Journal of Dairy Science 56: 896-902.

Kennedy VC, Gaspers JJ, Mordhorst BR, Stokka GL, Swanson KC, Bauer ML and Vonnahme KA, 2019. Late gestation supplementation of corn dried distiller's grains plus soluble to beef cows fed a low-quality forage: III. effects on mammary gland blood flow, colostrum and milk production, and calf body weights. Journal of Animal Science 97: 33373347. https://doi.org/10.1093/jas/skz201.

Lacasse P and Prosser CG, 2003. Mammary blood flow does not limit milk yield in lactating goats. Journal of Dairy Science 86: 2094-2097.

Linzell J, 1974. Mammary blood flow and methods of identifying and measuring precursors of milk. In: Larson BL and Smith VR (eds), Lactation. Academic Press, New York, USA, pp: 143.

Maltz E, Blatchford DR and Peaker M, 1984. Effects of frequent milking on milk secretion and mammary blood flow in the goat. Quarterly Journal of Experimental Psychology 69: 127 132.

Rasmussen F, 1963. The mammary blood flow in the goat as measured by antipyrine absorption method. Acta Veterinaria Scandinavica 4: 271-280.

Rasmussen F, 1965. The mammary blood flow in the cow as measured by antipyrine absorption method. Acta Veterinaria Scandinavica 6: 135-149.

Renaudeau D, Lebreton Y, Noblet J and Dourmad J 2002. Measurement of blood flow through the mammary gland in lactating sows: Methodological aspects. Journal of Animal Science 80: 196-201.

Smuts MS, Bezuidenhout AJ and Mazierski D, 1987. Anatomy of the Dromedary. Clarendon Press, Oxford, UK, pp: 221-222.

Thompson PD and Pike TL, 1973. Effect of milking stimuli on teat cisternal pressure and udder blood flow in a lactating cow. Journal of Dairy Science 56: 657.

Wilson C, Lammertsma A, McKenzie C, Sikora K and Jones T, 1992. Measurements of blood flow and exchanging water space in breast tumors using positron emission tomography: a rapid and non-invasive dynamic method. Cancer Research 52: $1592-1597$. 